Robert Kantor

Pontifical University of John Paul II in Krakow, Poland

\title{
Review
}

\section{The Authority of the Pope and the College of Bishops in the Church. Theological Nature and Mutual Relations, According to Fr. Piotr Semenenko CR, Fr. Paweł Obiedziński, ISBN: 978-83-7438-387-5, Cracow 2014, p. 320}

The Academic Publishing House of the Pontifical University of John Paul II in Cracow issued a book entitled "The Authority of the Pope and the College of Bishops in the Church. Theological Nature and Mutual Relations According to Fr. Piotr Semenenko CR” (pl. "Władza papieża i kolegium biskupów w Kościele. Natura teologiczna $i$ wzajemne relacje w ujęciu ks. Piotra Semenenki CR"), written by Fr. Paweł Obiedziński.

The matter of authority in the Church is one of the most current issues, not only theologically, but also in the sphere of legal considerations. The author recognises the question of authority based on the teachings of Fr. Piotr Semenenko, a prominent Polish theologian at the time of the First Vatican Council, who was born on 29 June 1814 in Dzięciołów, a village under Russian rule. He was, among others, a Consultor to the Sacred Congregation of the Index and a Consultor to the Sacred Congregation of the Holy Office.

The reviewed book consists of a preface by the Dean of the Faculty of Theology at the Pontifical University of John Paul II, Section in Tarnow, Fr. Prof. Janusz Królikowski, $\mathrm{PhD}$, an introduction, five chapters, conclusion and bibliography.

The first chapter, of historical and theological nature, consists of four parts. The first one presents the life and work of Fr. Piotr Semenenko, the second part deals with the basics of the Trinitarian Exemplarism, the third one outlines the background of the issue of authority according to Fr. Semenenko, and the last one discusses heterodox approaches, which greatly influenced the ecclesiology in the $19^{\text {th }}$ century (pp. 23-83). 
The second chapter covers the issue of authority. It is about authority in the Church, its nature, as well as the problems of jurisdiction and infallibility. This infallibility was presented in two aspects: as a gift from God given to the Church and as a privilege of infallibility, owing to which the Church is never wrong, but by the power of God, it requires the faithful to embrace the faith (pp. 85-142).

In the third chapter, the nature and character of papal authority in the Church was described using Fr. Piort Semenenko's teaching. Thus, in the first part of this chapter, the pope was presented as a link connecting Christ to the Church. In the second part, the grounds to illustrate the pope's infallibility were drawn from the determination that he is the foundation of faith. In the third part, the nature and character of the papal jurisdictional authority were determined by reference to the supernatural virtue of hope, and the fourth part presents the unity of papal authority upon the foundation of the virtue of love. For Fr. Piotr Semenenko, the pope is the foundation of the virtue of love. The supernatural life of the Church stems from love, which leads to its unity, which is, in turn, guaranteed and personified by the pope, as instituted by Christ (pp. 143-220).

In the fourth chapter, the author demonstrated the nature and theological character of bishops' authority in the Church. Also, the place of authority and rights of certainentities are presented. In this chapter, starting from the concept of papacy as the supreme authority, the author proceeds to show the relationship between the entities. This relationship shows the dependence of both the College and individual bishops on the authority of the pope, as well as indicates the appropriate object of power, defining the terms of union with the pope (pp. 221-284).

The fifth chapter is a summary of all the considerations, presenting a hierarchical and Trinitarian nature of authority (pp. 285-306).

The objective of the book presented in the introduction is to "demonstrate the ecclesiological and Trinitarian teaching of Piotr Semenenko which may have a significant impact on the systematic and speculative method, which is neglected in the present-day theology".

The work of Fr. Paweł Obiedziński undoubtedly illustrates the ecclesiology of Fr. Piotr Semenenko, a prominent Polish theologian. On the other hand, one may ask whether the use of metaphysical concepts makes sense today. When I took the book in my hands, I expected to find more legal references. The central point of the canonical doctrine is the question whether potestas regiminis understood as the power of governance is inextricably connected with potestas 
sacra, understood as the general ontological capabilities of the sacred ministers. The source of the jurisdictional authority in the Church is fully sacramental in its source: its origin has to be discerned in the power entrusted to the pope and to all those who form the College with him. However, the problem is how to determine in which way potestas regiminis is transmitted from this source to other entities. Of course, these issues are strictly canonical and it cannot be expected from the reviewed work to undertake this canonical aspect, although it could be very interesting, but beyond the objective outlined by the author.

The book can serve as an inspiration to take up the issue of the authority of the pope and the College of Bishops in the Church in the contemporary theological and canonical thought. It is hoped that such interdisciplinary research, taking into account the rich canonical content, will be undertaken by theologians. 